\title{
Comments
}

\section{New Problems with Removal and the ALI*}

\section{INTRODUCTION}

One version or another of 28 U.S.C. $\$ 1441$, the federal removal jurisdiction statute, has existed since the Judiciary Act of $1789 .{ }^{1}$ The removal statute provides defendants with the opportunity to choose the forum they prefer, if there is a choice between a federal or state forum. The rationale is that the defendant did not choose to be sued, and because she did not initiate the suit, she had no choice in where the suit would be tried. $^{2}$ Thus, the plaintiff potentially has an unfair advantage over the defendant, because the plaintiff will choose the forum that is either most advantageous to her or least advantageous to the defendant.

The state court may be more advantageous to the parties than the federal court for a number of reasons. For example, the presiding judge in the state court may be more inclined to find for plaintiffs, the absence of a jury may be relevant, or it may be the case that the state court is less crowded than the federal court. And so, because of the possible advantages or disadvantages associated with state or federal court in a case where either court may have jurisdiction, it has long been held that if the defendant objects to the forum where the suit is brought, it is the defendant's right to remove the case (at least to the federal court).

The removal statute is divided into three subsections. The first two subsections, $\S 1441$ (a) and (b), allow the defendant to remove the suit to federal court if the federal court would have had jurisdiction over the entire suit originally. ${ }^{3}$ Section 1441 (c) allows the action to be removed in a suit where the claims are mixed, i.e., where there are some claims over which the state has jurisdiction, and different claims over which the federal court would have jurisdiction as well. Neither $\S 1441(a)$ nor $\S$

* Rebecca Martin. I would like to thank Professor Ellen Sward for her assistance with my topic and Professor Laura Hines for her helpful suggestions.

1. Edward Hartnett, A New Trick from an Old and Abused Dog: Section 1441(c) Lives and Now Permits the Remand of Federal Question Cases, 63 FordHAM L. REV. 1099, 1103-04 (1995).

2. Id. at 1105 .

3. 28 U.S.C. $\S 1441(a)-(b)(2003)$. 
1441(b) would allow removal in these circumstances because they require all claims to have original jurisdiction in the federal court. ${ }^{4}$

Section 1441(c) reads as follows:

Whenever a separate and independent claim or cause of action within the jurisdiction conferred by section 1331 of this title is joined with one or more otherwise non-removable claims or causes of action, the entire case may be removed and the district court may determine all issues therein, or, in its discretion, may remand all matters in which State law predominates.

There have been several persistent problems with $\S$ 1441(c). First, it is not entirely clear what can and cannot be removed under $\S 1441$ (c). The courts are split with regard to removal by third-party, cross-claim, and counterclaim defendants. ${ }^{6}$ For example, the majority holds that third-party removal is unacceptable, but the minority position is that third-party removal is acceptable. ${ }^{7}$ Not allowing these defendants to remove may cause many unfair outcomes.

Second, the statute as currently drafted allows federal question claims $^{8}$ to be remanded to state court. The section provides that "the district court ... in its discretion, may remand all matters in which State law predominates." 9 Thus, the federal court may send the suit back to state court, even if there is a federal question, as long as the court decides that the "predominant" issue is not the federal question.

Third, the statute as it stands today employs the "separate-andindependent" test to determine whether a claim is removable to federal court. ${ }^{10}$ Many consider this test to be not only ambiguous but also superfluous because a similar test, the "relationship" test, is used by the supplemental jurisdiction statute to determine if a state claim may be

4. $\S 1441(\mathrm{c})$.

5. Id.

6. Compare Lewis v. Windsor Door Co., 926 F.2d 729, 733 (8th Cir. 1991); Sterling Homes, Inc. v. Swope, 816 F. Supp. 319, 321 (M.D. Pa. 1993); Elkhart Co-op Equity Exch. v. Day, 716 F. Supp. 1384, 1388 (D. Kan. 1989); Share v. Sears, Roebuck \& Co., 550 F. Supp. 1107, 1109 (E.D. Pa. 1982); and Lowe's of Montgomery, Inc. v. Smith, 432 F. Supp. 1008, 1013 (M.D. Ala. 1977) (all holding that third-party removal is not allowed); with Carl Heck Eng'rs v. LaFourche Parish Police Jury, 622 F.2d 133, 135 (5th Cir. 1980); Soper v. Kahn, 568 F. Supp. 398, 405 (D. Md. 1983); Peturis v. Fendley, 496 F. Supp. 203, 205 (S.D. Ala. 1980); and Ted Lokey Real Estate Co. v. Gentry, 336 F. Supp. 741, 743 (N.D. Tex. 1972) (all holding that third-party removal is acceptable).

7. See cases cited supra note 6 .

8. A federal question claim requires the application of federal law to an issue presented in the cause of action. 28 U.S.C. $\S 1331$ (2000).

9. 28 U.S.C. $\S 1441(\mathrm{c})(2003)$.

10. Am. Fire \& Cas. Co. v. Finn, 341 U.S. 6, 9 (1951). 
heard in federal court. ${ }^{11}$ Because the two tests are performing essentially the same function, it has been argued that the separate-and-independent test should be eliminated and replaced with the less ambiguous relationship test. ${ }^{12}$

In 1990, Chief Justice Rehnquist created the Federal Courts Study Committee, which recommended that Congress repeal $\S 1441$ in part because the statute did not allow diversity jurisdiction. ${ }^{13}$ However, Congress refused to do so. In its most recent revision of the removal statute, it felt it was necessary to retain $\S 1441$ to prevent a plaintiff from defeating removal by joining an unrelated state claim to a federal question case. ${ }^{14}$ The House Report noted that the joinder rules of many states allow a plaintiff to join a completely unrelated state claim. ${ }^{15}$ Without $\S 1441(\mathrm{c})$, a plaintiff joining a state claim would defeat removal because of the requirement that the federal court have jurisdiction over every claim in the suit. If an unrelated claim could in fact be joined, it would be particularly easy for a plaintiff to defeat removal. She could, for example, attach a practically meritless negligence claim to a substantial patent infringement claim. Without $\$ 1441(\mathrm{c})$, the defendant would not be permitted to remove the case to federal court, although federal court would probably be where the case belonged.

Finally, the American Law Institute (ALI) began its Federal Judicial Code Revision Project in $1994 .^{16}$ It recently released its report of this project. The project covers "three topics in which current statutes could be clearly demonstrated to be working sub-optimally: supplemental jurisdiction, removal, and venue."17

The ALI makes three findings regarding removal. First, the ALI adopts the majority view and disallows removal by third-party, crossclaim, and counterclaim defendants. ${ }^{18}$ In adopting this view, the ALI argues that the removable federal claim must be present in the initial

\footnotetext{
11. Am. Law Inst., Federal Judicial Code ReVision Project 512 (2004).

12. Id.

13. Federal Courts Study Comm., Report of the Federal Courts Study Committee 94-95 (1990).

14. Hartnett, supra note 1, at 1145 .

15. H.R. REP. NO. 101-734, at 23 (1990).

16. AM. LAW INST., supra note 11, at 1 . The ALI began this project in honor of its twenty-fifth anniversary. In 1959, Chief Justice Earl Warren asked the ALI to engage in such a project, and it did so, resulting in "enormous influence on the thinking of the bench, the bar, and the academy." Id. But Congress was not persuaded to accept all of its recommendations. In light of that, the ALI decided to try again. $I d$.

17. Id. at 2.

18. Id. at 333
} 
pleadings. ${ }^{19}$ Thus, cross-claim, counterclaim, and third-party defendants cannot remove because it is likely that the federal claim upon which they base the power to remove was not included by the plaintiff in the first pleading.

Second, the ALI's revisions attempt to disallow federal questions from being remanded to state court. The revisions eliminate the judicial power of discretion to remand claims to state court, and instead require that judges remand certain claims. ${ }^{20}$ The ALI would change the statute to preserve federal subject matter jurisdiction by requiring that all federal claims and state claims that are a part of the same case or controversy remain in federal court. ${ }^{21}$

Third, the ALI would change the criterion used to determine whether an action is removable from "separate and independent" 22 to a removable claim being one attached to a claim that is "not part of the same case or controversy under Article III of the Constitution." 23

The ALI's suggestions fall short of perfecting an imperfect statute. First, the decision not to allow third-party, cross-claim, or counterclaim defendants removal privileges is a mistake. Second, the revision that disallows judges the discretion to remand federal question cases to state court in turn allows piecemeal litigation, which is less than desirable. However, the replacement of the separate and independent test with the relationship test is a good change because it collapses two tests into one. This change, if adopted, would probably result in less confusion among attorneys and courts because there would be one less test to master.

This Comment will first examine the problems that currently exist with the last section of the federal removal statute. Then, the Comment will examine the ALI's suggestions for amending the statute to correct the current problems. Finally, the Comment will offer both a critique of the ALI recommendations and suggestions for improving them.

\section{BACKGROUND: A BRIEF HISTORY OF REMOVAL}

Beginning with the Judiciary Act of 1789 , a case could be removed when all claims fell within federal jurisdiction. ${ }^{24}$ This allowed for state

\footnotetext{
19. Id.

20. Id. at 374 .

21. Id. at 372 .

22. 28 U.S.C. $\S 1441(c)$ (2003).

23. AM. LAW INST., supra note 11, at 333-34.

24. Hartnett, supra note 1, at 1103.
} 
joinder rules to block removal. ${ }^{25}$ (For example a state claim could be joined to the federal claim, thus preventing the case from being removed because not all claims fell within federal jurisdiction.) To prevent the plaintiff from blocking removal by using state joinder rules, Congress revised the statute in 1866 to allow "piecemeal removal." removal permits parts of a case to be removed to federal court, while other parts of the case remain in state court. Because of the confusion it caused within the courts, piecemeal removal was soon abandoned. ${ }^{27}$ Congress instead enacted a special removal statute to avoid the state joinder rules (this statute eventually evolved into $§ 1441(\mathrm{c})$ ). ${ }^{28}$

Although Congress had abandoned piecemeal removal in 1948, some courts continued to allow it. ${ }^{29}$ To stop the courts from using piecemeal removal, Congress enacted $\S 1441(\mathrm{c}){ }^{30}$ Piecemeal removal was no longer necessary because $\S 1441$ (c) allowed for removal of the entire case if even a single separate removable claim existed therein. ${ }^{31}$ The statute allowed removal in instances of both diversity and federal question jurisdiction. $^{32}$

In 1990, Chief Justice Rehnquist created the Federal Courts Study Committee to assess the state of federal jurisdictional laws. ${ }^{33}$ The committee recommended that $\S 1441$ (c) be abolished because of the confusion caused by removal of diversity jurisdiction cases. ${ }^{34}$ The committee asserted that removal jurisdiction helped in such a limited number of federal question cases that it was not necessary to retain the section. ${ }^{35}$

In 1990, Congress enacted the Judicial Improvements Act. ${ }^{36}$ It did not accept the recommendation of the Federal Courts Study Committee to abolish the statute; instead it revised the statute. The revision of $\S$ 1441(c) eliminated removal in circumstances where federal jurisdiction was conferred on the federal claim because of diversity jurisdiction (following the suggestions of the Federal Courts Study Committee).

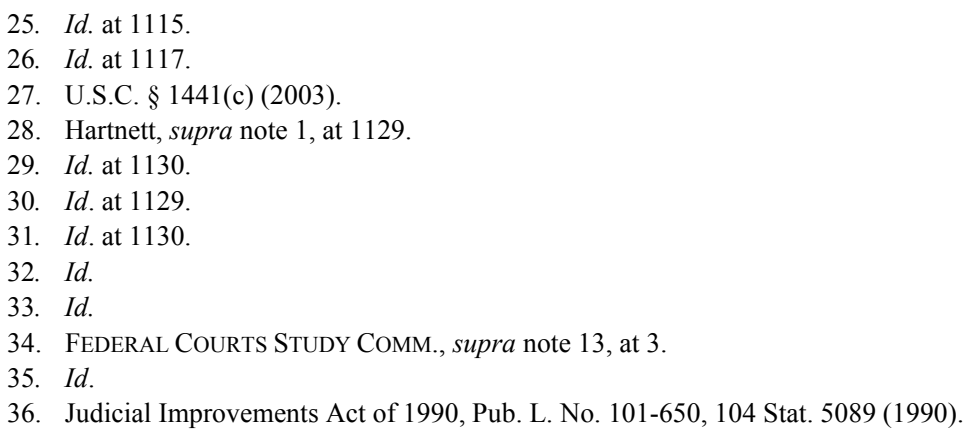


Congress felt it necessary to retain $\S 1441$ (c) because it was the only section of the removal statute that allowed a defendant to remove a case even if the plaintiff was attempting to block the removal through the use of state joinder rules. The other sections of the statute require that every claim in the case fall under the original jurisdiction of the federal court. ${ }^{37}$ Thus, a plaintiff could join a meritless state claim to her federal claim, and removal would become impossible for the defendant. This problem is known as "fraudulent joinder." Section 1441(c) prevents fraudulent joinder because it allows actions that include both federal and state claims to be removed to federal court.

\section{ANALYSIS}

\section{A. Removal by Third-Party, Cross-Claim, and Counterclaim Defendants}

The courts have adopted different views about whether third-party, cross-claim, and counterclaim defendants are able to remove actions to federal court under $\S 1441(\mathrm{c}){ }^{38}$ Although prima facie the statute does not appear to prevent one of these defendants from removing, most courts have decided that congressional intent was to prevent them from doing so. ${ }^{39}$

\section{The Problem}

Counterclaim, cross-claim, and third-party issues have arisen in connection with $\S 1441$ (c). For example, in Verschell v. Fireman's Fund Insurance Co., the district court held that no defendant in any cross claim filed after the plaintiff's complaint had been issued had a right of removal, unless the right of removal arose from the original plaintiff's complaint. ${ }^{40}$ This result is problematic because it is potentially unfair to defendants either named in the original action or brought into the action by a named defendant. Consider the following example: $A$ sues $B$ in state court, and $A$ 's complaint includes no removable claim. Then, $B$

37. 28 U.S.C. $§ 1441(a)-(b)(2003)$.

38. See cases cited supra note 6.

39. See, e.g., Lewis v. Windsor Door Co., 926 F.2d 729, 733 (8th Cir. 1991); Elkhart Coop. Equity Exch. v. Day, 716 F. Supp. 1384, 1388 (D. Kan. 1989); Share v. Sears Roebuck \& Co., 550 F. Supp. 1107, 1109 (E.D. Pa. 1982); Lowe's of Montgomery, Inc. v. Smith, 432 F. Supp. 1008, 1013 (M.D. Ala. 1977) (all holding that third-party removal is not allowed).

40. 257 F. Supp. 153, 154 (S.D.N.Y. 1966). 
joins $C$ as a defendant to the suit. When $B$ joins $C$ as a defendant, $B$ also brings a cross claim against $C$. The cross claim that $B$ brings involves a federal question. Under the Verschell holding, $C$ would not be able to remove the case to federal court because $C$ is a defendant in a cross claim "thereafter filed" and thus has no right of removal. ${ }^{41}$

The same problem may arise with counterclaims. Consider the following example: $A$ sues $B$ in state court, and $A$ 's complaint includes no removable claim. Then, $B$ states a counterclaim that contains a federal question in her pleadings against $A$. If $A$ wishes to remove the claim to federal court, on the rationale of the Verschell court, she would be unable to do so because the joinder of claims that allows removal to federal court by $\S 1441$ (c) refers to the joinder of claims by the plaintiff. ${ }^{42}$ Under Verschell, there is no reason to allow a party to remove a suit to federal court when the original pleadings contain no removable claim, whether the party interested in removing is an original plaintiff or an original defendant.

In the example above, however, the plaintiff could attach a federal question claim to her complaint and remove to federal court. This result is problematic because the plaintiff is being compelled to seek a new cause of action that likely has little merit because it is one that the plaintiff created just to try the case in federal court. Today's dockets are already crowded enough and the court should not encourage an increase in litigation because of procedure.

Are these results anticipated by $\S 1441(\mathrm{c})$ ? Are they the results that Congress intended? It is unlikely that disallowing these parties from removing was Congress's intention. The rationale behind allowing a defendant to remove a case is that the defendant, who is not choosing to be sued, has no control over the forum in which the plaintiff brings the suit. $^{43}$

In the first example, $C$ had no choice about being sued by either $A$ or $B$. Further, $C$ had no control over the forum in which the suit was brought. Thus, there is no difference between a defendant who has the option of removing to federal court because the plaintiff brought a federal question claim and the defendant who is not only brought into the suit by another defendant, but is further sued by that defendant in a cross claim. $C$ should have the right to remove the case to federal court.

\section{Id.}

42. Id.

43. See Haden P. Gerrish, Third-Party Removal Under Section 1441(c), 52 FORDHAM L. REV. 133,141 (asserting that a third-party defendant, like an original defendant, may need the protection of the removal laws). 
One could argue that removal would be unfair to the original plaintiff, though, because the plaintiff has a right to have her state claim case heard in state court, where the court has more authority to interpret and apply state laws. But having her case removed to federal court is a risk the plaintiff must take. It is not fair to prevent a defendant from removing to federal court on grounds that the plaintiff has a right to have her case heard in state court when the defendant has no choice about being sued. The defendant should have some say in where the action is brought, if it is possible for the action to be brought in multiple fora.

\section{The Split Among the Courts}

The majority view among courts is that third-party defendants may not remove a case. ${ }^{44}$ Courts that do not allow third-party removal have made a two-pronged argument against it. ${ }^{45}$ First, courts "start with the federalist principle that removal statutes are to be strictly construed against removal because they serve to broaden the jurisdiction of federal courts at the expense of state courts." ${ }^{46}$ The authority for this view comes from Shamrock Oil \& Gas Corp. v. Sheets. ${ }^{47}$ Shamrock requires that removal statutes be strictly construed against removal, giving "“[d]ue regard for the rightful independence of state governments." "48 The Supreme Court felt strongly that federal courts should not overstep their jurisdictional boundaries. ${ }^{49}$

Then, these courts focus on the language of $\S 1441(\mathrm{c})$. Courts that do not permit third-party removal argue that the statute clearly does not allow third-party removal for two reasons. ${ }^{50}$ First, $\S 1441(\mathrm{c})$ speaks to "joined" claims: a separate and independent claim must be joined with one or more otherwise nonremovable claims. ${ }^{51}$ Courts have interpreted

\footnotetext{
44. E.g., Share, 550 F. Supp. at 1109; Lowe's of Montgomery, Inc., 432 F. Supp. at 1013.

45. Starr v. Prairie Harbor Dev., 900 F. Supp. 230, 232 (E.D. Wis. 1995).

46. $I d$.

47. 313 U.S. 100 (1941).

48. Id. at 109 (quoting Healy v. Ratta, 292 U.S. 263, 270 (1934)).

49. Id. at $108-09$.

50. Some courts have also articulated a third reason for not permitting third-party removal. They argue that history demonstrates that third-party removal should not be allowed. They argue that $\S 1441$ (c) was passed to restrict the right of removal. See, e.g., Am. Fire \& Cas. Co. v. Finn, 341 U.S. 6, 9-10 (1951). Further, the Judiciary Act of 1887-88 limited removal to defendants. Finally, the recent restriction against diversity jurisdiction as being appropriate grounds for removal indicates that Congress intends for the statute to apply to as few cases as possible. See Sterling Homes, Inc. v. Swope, 816 F. Supp. 319, 322 (D. Pa. 1993) (articulating a similar argument to the one just advanced).

51. 28 U.S.C. $§ 1441$ (c) (2000)
} 
this language as being complaint oriented and governed by the rules of joinder. ${ }^{52}$ In other words, only a plaintiff may join claims in the original complaint. ${ }^{53}$ The courts argue that a "third-party complaint is not technically joined but is antagonistic to the original claims of the plaintiff., 54

This argument is flawed. Rule 18 of the Federal Rules of Civil Procedure governs joinder of claims. ${ }^{55}$ Rule 18(a) asserts that "a party asserting a claim to relief as an original claim, counterclaim, cross-claim, or third-party claim" ${ }^{\prime 56}$ may join as many claims as the party wishes. The rule does not specify that only a plaintiff may join claims; as a matter of fact, the rule makes it exceedingly clear that any party in the action may join claims. ${ }^{57}$ Thus, $\S 1441$ (c)'s reference to joined claims does not clearly indicate that Congress intended for the statute to apply to only those claims joined by the plaintiff.

State rules of civil procedure regarding joinder frequently mirror the federal rule. ${ }^{58}$ Consequently, it cannot be argued that the state rules, which are the rules that govern when the plaintiff brings the action, and the joinder rules, which govern the addition of parties to the action that join in the context of state rules, refer only to the plaintiff.

Second, the majority of courts argue that because $\S 1441$ (a) of the removal statute states that any action in which the United States would have original jurisdiction "may be removed by the defendant or the defendants," $59 \S 1441$ (c) also requires that the action be removed by the original defendant. If courts choose to adopt a very limited definition of "defendant" - such as, a defendant is only the original party being sued in a suit - that definition does not necessarily extend to $\$ 1441$ (c), which does not itself include the word defendant. Section 1441(a) is not a preamble to the statute that indicates policy applicable to the entire statute, but a specific, independent section of the statute.

For example, $\S 1441$ (c) limits mixed federal-state claims that may be removed to federal court to claims that are conferred federal jurisdiction because of federal questions (thus eliminating diversity jurisdiction as

52. Swope, 816 F. Supp. at 322-24.

53. Id. at 323 .

54. Id.

55. FED. R. CIV. P. 18.

56. Id. (emphasis added).

57. See also Gerrish, supra note 43, at 140 (arguing that this argument is flawed because joinder is not particular to plaintiffs).

58. E.g., Kan. Stat. AnN. § 60-218(a) (1994); AlA. R. Civ. P. 18(a); ARIZ. R. Civ. P. 18(a); ME. R. CIV. P. 18(a) (all of these rules are identical to FED R. CIV. P. 18(a)).

59. 28 U.S.C. $\S 1441(a)(2003)$. 
possible grounds for removal). But this rule is not applicable under $\S$ 1441(a), which makes no such limitation: a claim that is conferred federal jurisdiction because of diversity is removable. ${ }^{60}$ These courts recognize that the third-party defendant has no forum choice without removal, as in the case of original defendants. But they think that preserving the state's jurisdiction supersedes the interest of the thirdparty defendant. ${ }^{61}$

Although one may argue that the circumstances demand that the statute be read in pari materia, because the language of $\S 1441$ (c) is ambiguous, it still is not reasonable to assume that the word defendant means only the original defendant. A statute may be read in pari materia if it is ambiguous. ${ }^{62}$ This rule of construction stipulates that statutes that relate to the same subject matter should be read, construed, and applied together so that the legislation's intent can be gathered from the whole of the enactments. ${ }^{63}$ Even if the statute is read in pari materia, the word defendant in $\S 1441$ (a) does not necessarily connote the original defendant. A party who has been brought into an action-for example, on an indemnity claim - is no less a defendant than the original defendant.

The minority position allows third-party removal. ${ }^{64}$ Although these courts also begin with the Shamrock principle of narrow construction, ${ }^{65}$ they disagree with the majority's interpretation of the removal statute. These courts have adopted several strategies for third-party removal, which were described in Sterling Homes Inc. v. Swope. ${ }^{66}$ The court asserted that: (1) few courts allow removal of the entire case; (2) others allow third-party removal of the "severed part," and (3) other courts permit third-party removal in theory, but have not yet had a case where they have decided that removal was appropriate. ${ }^{67}$

60. Id.

61. Id.

62. See BLACK's LAW DiCTIONARY 807 (8th ed. 2004) ("[S]tatutes that are in pari materia may be construed together, so that inconsistencies in one statute may be resolved by looking at another statute on the same subject."). Also, I would like to thank my comment editor, Sarah Lepak, for suggesting that the statute be read this way.

63. See id.

64. E.g., Carl Heck Eng'rs, Inc. v. LaFourche Parish Police Jury, 622 F.2d 133, 135 (5th Cir. 1980); Soper v. Kahn, 568 F. Supp. 398, 405 (D. Md. 1983); Peturis v. Fendley, 496 F. Supp. 203, 205 (S.D. Ala. 1980); Ted Lokey Real Estate Co. v. Gentry, 336 F. Supp. 741, 743 (N.D. Tex. 1972) (all holding that third-party removal is acceptable).

65. See supra notes 47-49 and accompanying text.

66. 816 F. Supp. 319, 321-22 (M.D. Pa. 1993).

67. Id. 
For example, the Fifth Circuit permits third parties to remove cases to federal courts under $\S 1441(\mathrm{c})$, as long as the third party "allege[s] a separate and independent claim which was independently removable." 68 That courts allow removal of the "severed part" seems irrelevant, though, because courts are given discretion by the statute to remand all matters in which the state law predominates. ${ }^{69}$ Accordingly, the court always has discretion to remand the rest of the case back to state court.

The minority argues that the majority is wrong for the aforementioned reasons. ${ }^{70}$ If Congress intended for "join" to apply only to the plaintiff, then it easily could have said so. ${ }^{71}$ The minority argues that a narrow Shamrock construction of the statute ${ }^{72}$ does not entail adding language (e.g., the word "plaintiff") to the statute. These courts have adopted a more functional approach in determining who is a defendant, and they allow third-party defendants to qualify as defendants of the kind that Congress is addressing in $\S 1441(a)^{73}$ (although they could also choose to ignore this argument, as $\S 1441$ (c) does not include the word defendant anyway ${ }^{74}$ ). These courts argue that the third-party defendant has no more choice of forum than the original defendant and so is afforded the same protection by the removal statute. ${ }^{75}$

\section{The Solution from the ALI's Federal Judicial Code Revision Project}

The American Law Institute's revisions to $\S 1441$ (c) do not appear to address this issue, although the revisions to $\S 1441$ (a) do address the issue. Section 1441(a) of the removal statute is the provision that allows removal of "civil actions" where the federal court maintains original jurisdiction. ${ }^{76}$ Section 1441(a)(2) asserts that a case may be removed by the defendant if "every claim asserted in the complaint or other initial pleading is a removable claim." 77 Allowing only claims asserted in the initial pleading to be removed does not allow for third parties to remove

\footnotetext{
68. BJB Co. v. Comp Air Leroi, 148 F. Supp. 2d 751, 754 (N.D. Tex. 2001).

69. 28 U.S.C. § 1441(c) (2003).

70. See supra Part III.A.1.

71. Sterling Homes, 816 F. Supp. at 323.

72. See supra notes 47-49 and accompanying text.

73. Sterling Homes, 816 F. Supp. at 324.

74. § 1441(c).

75. Sterling Homes, 816 F. Supp. at 324.

76. $\S 1441(\mathrm{a})$. This statute allows removal based on jurisdiction acquired either by diversity or a federal question, unlike $\S 1441(\mathrm{c})$. A further contrast between this section and $\S 1441(\mathrm{c})$ is that in $\S 1441$ (c), a case may be removed based on an individual claim, whereas in $\S 1441$ (a) the whole case must fall under the federal court's jurisdiction.

77. AM. LAW INST., supra note 11, at 333 (emphasis added).
} 
a claim to federal court, nor does it allow for claims in cross claims or counterclaims to be removed, because the claims in these cases would not be included in the initial pleading. The reporter claims that this provision "makes clear what present law merely implies."78 But, as is addressed above, it is unclear what present law implies, as can be seen by the split in the courts over whether third parties may remove. ${ }^{79}$ So it is unclear why the reporter treats the issue as if it is uncontroversial.

Then, the revised version of $\S 1441$ (c) asserts that if a claim is removable based on 28 U.S.C. $\S 1331$ (the statute granting federal question jurisdiction to the federal court), but attached to a nonremovable claim, it may be removed "as provided by subsection (a)." ${ }^{" 80}$ Thus, one is sent back to the provisions for removal set out by $\S 1441(\mathrm{a})$, including the provision that every claim asserted in the complaint or other initial pleading may be removed. So third-party removal, or removal of a claim asserted in a cross claim or counterclaim, is also not allowed for under the ALI's new subsection (c).

When the ALI first considered this problem, it determined that thirdparty removal was acceptable in diversity cases. ${ }^{81}$ But it worried that defendants would implead parties for the sole reason of removing the case to federal court. ${ }^{82}$ For example, a defendant may implead a manufacturer with corporate headquarters in a different state. Then, the third-party defendant could remove the case to federal court. To avoid this situation, the ALI would not allow parties to remove if the parties held certain relationships (e.g. employer/employee) or if they were insured by the same liability insurer. ${ }^{83}$ But now the ALI does not believe that third-party removal should be allowed even for diversity cases. ${ }^{84}$

\section{A Critique of the ALI's Position}

The ALI and the majority made the wrong decision in not allowing third-party, counterclaim, and cross-claim removal. The policy considerations that the majority believes should prevent third parties from removing do not outweigh the unfairness of the result to third-party,

78. Id. at 351

79. See supra Part III.A.2.

80. AM. LAW INST., supra note 11, at 334.

81. See id. at 333 (permitting removal of diversity cases under $\S 1441(\mathrm{~b})$ ).

82. Am. Law InSt., Study OF THE Division OF JuRisdiction Between State and Federal COURTS $\S 1304(b)$, at 16-17, 144-46 (1969).

83. Id.

84. AM. LAW INST., supra note 11, at 351-52. 
cross-claim, or counterclaim defendants. Although in the instances of cross-claim and third-party defendants there is a possibility that plaintiffs may be taken to federal court even when they have not introduced a federal jurisdiction claim into the suit, this risk is one that plaintiffs must bear for several reasons.

First, it is unclear from the statute whether Congress intended to include cross-claim, counterclaim, or third-party defendants. Even if it is conceded that Congress meant for the term defendant from $\S 1441$ (a) to apply to $\S 1441$ (c) as well, it is far from clear that the "law implies" that cross-claim and third-party defendants do not qualify as defendants. If cross-claim, counterclaim, and third-party defendants are not defendants, then what are they?

If Congress had intended to exclude these parties from removing claims to federal court, then it could have said so in the statute, it could have provided a definition of defendant that excluded the aforementioned parties, or it could have easily modified the word defendant with the word "original." If the statute said that an action "may be removed by the original defendant" then it would be clear that Congress intended to exclude third-party, cross-claim, and counterclaim defendants. But there is no reason to read a special definition of the word "defendant" into the statute. And, because this is the only justification that the reporter provides for the ALI exclusion of these defendants, ${ }^{85}$ the change ought not to have been made.

Furthermore, because no distinction should be made between the original defendant and defendants who later become parties to the suit, the later-joined defendants are owed the same rights as the original defendants. It seems particularly unfair that a party would be denied the right to remove just because she was not first in line-either she was not an original party to the suit or the original pleadings did not include a federal claim. If the third-party, cross-claim, or counterclaim defendant had been sued in a separate lawsuit, she would have the right to remove. But instead, she was unlucky enough to be included in a suit where she was not sued in the original pleadings or where a federal claim conferring jurisdiction was introduced later, and not in the original pleadings.

There are two final policy problems to be considered with the position that third-party, cross-claim, and counterclaim defendants should be allowed to remove. First, this position may force plaintiffs to contemplate every party that may be joined to a suit. This may become 
expensive because of accruing legal fees, or it may even be impossible. If the plaintiff wants the suit to stay in state court and has not included any federal claims, then it is probably unfair to require the plaintiff to contemplate all of the parties that may be attached to the suit by the defendant.

This worry leads to a second policy problem - fraudulent joinder of claims by the defendant. ${ }^{86}$ Consider the following example: $A$ sues $B$ and $C$ in state court. $A$ does not include any federal claims in her complaint. $B$ and $C$ would prefer the action to be tried in federal court, because trying the action in federal court would probably result in case disposition decided by a judge, whereas it is more likely that a jury will decide the case in state court. ${ }^{87}$ But neither $B$ nor $C$ is able to remove the action to federal court because the federal court does not have jurisdiction. So, $B$ files a cross claim against $C$ that includes a federal question, which confers federal jurisdiction to the claim.

$B$ introduces the claim only so $C$ will remove the case to federal court; otherwise the claim has no merit. On this view, $C$ could then remove the case to federal court, where $B$ and $C$ believe the conditions would be more favorable to them, based on a claim introduced for the sole purpose of allowing removal. This Comment's position could even encourage $B$ and $C$ to collude with each other and agree that $B$ should sue $C$ so they can remove to federal court.

However, this last result is unlikely. First, the federal court maintains the discretion to remand all claims that are not federal back to state court. This would probably leave the plaintiff in state court in most instances. For instance, in the example, the federal court could leave only the federal claim between $B$ and $C$ in the federal court and send the other claims ( $A$ 's claims) back to the state court. Second, sanctions can be brought against parties that introduce frivolous litigation, and bringing a claim just so the suit may be removed to federal court probably qualifies as frivolous. ${ }^{88}$ Even if the plaintiff could not argue for

86. It is unclear if the term "fraudulent joinder" applies only to acts in which the plaintiff attaches to her pleadings a claim over which the federal court does not have jurisdiction, just to prevent the defendant from being able to remove. If this is not the case, it certainly seems like the case described is the defendant's version of fraudulent joinder.

87. Neal Miller, An Empirical Study of Forum Choices in Removal Cases Under Diversity and Federal Question Jurisdiction, 41 AM. U. L. REV. 369, 424-25 (1992). Miller's empirical evidence in this article indicates that the most frequent reason that a defendant's attorney wants to remove a case to federal court is so the case will be decided by a judge. The most frequent reason a plaintiff's attorney would prefer for a case to stay in state court is the attorney's perception that it is more likely a jury will decide the case.

88. FED. R. CIV. P. 11 allows for sanctions to be brought against attorneys who introduce frivolous litigation. 
sanctions under Rule 11 of the Federal Rules of Civil Procedure because the plaintiff is not the victim of the frivolous lawsuit (the plaintiff is the victim, ultimately, but not in the manner intended by the rule, because the plaintiff is not being frivolously sued ${ }^{89}$ ), the court may bring Rule 11 sanctions sua sponte. ${ }^{90}$

In conclusion, the ALI should not prevent third-party, cross-claim, or counterclaim defendants from removing claims to federal court. Instead, the amendments to the statute should reflect the current intent (as it can be inferred) of Congress to allow all defendants the right of removal.

\section{B. The Federal Courts' Ability to Remand Federal Question Cases Back to State Courts}

\section{Can Federal Questions be Remanded?}

The last section of $\S 1441$ (c) states that the district court "may determine all issues [of the suit—both federal and state claims] ... or, in its discretion, may remand all matters in which State law predominates." 91 The language of this remand clause was changed by the Judicial Improvements Act of 1990 from the prior language of the statute, which stated that the district court had discretion to remand "all matters not otherwise within its original jurisdiction. $" 92$

This amendment appears to allow federal question claims to be remanded to state courts, as long as the federal question claim is not the dominant claim. Soon after the amendment was adopted, several commentators noted that "matters" could be construed widely enough to allow remand of the entire case. ${ }^{93}$ This demonstrates that not only could

89. Although, from a prima facie reading of the rule, there is no reason why the plaintiff could not make such a move. The rule requires only that the party filing the motion for sanctions demonstrate that "the claims . .. are not warranted by existing law". FED. R. CIV. P. 11(b)(2). There is no reason that the plaintiff could not demonstrate that this was the case, even though the claim in question pertained to parties other than the plaintiff.

90. FED. R. CIV. P. 11(c)(1)(B).

91. 28 U.S.C. $\S 1441(\mathrm{c})(2003)$.

92. Id.; Judicial Improvements Act of 1990, Pub. L. No. 101-650, § 312, 104 Stat. 5089, 5114 (1990).

93. E.g., Hartnett, supra note 1, at 1159; Thomas M. Mengler et al., Recent Federal Court Legislation Made Some Noteworthy Changes, NAT'L L.J., Dec. 31, 1990-Jan. 7, 1991, at 20-21; David D. Siegel, Changes in Federal Jurisdiction and Practice Under the New Judicial Improvements Act, 133 F.R.D. 61, 78 (1991). It should also be noted that Siegel wrote the commentary that accompanies the annotated version of the Amendment. David D. Siegel, Commentary on 1988 and 1990 Revisions of Section 1441, 28 U.S.C.A. $\S 1441$ (West 1994). In the commentary, he advances the same position that he advances in the aforementioned paper. See id. (stating that a court may remand a whole case to state court if state law predominates). 
single federal question claims be remanded to state court, but so could entire suits that may involve several federal question claims.

\section{The View of the Courts}

Although commentators mostly advised against this construction, ${ }^{94}$ initially federal district courts began to assert in dicta and holdings the power to remand entire federal question cases that had been removed from state courts. ${ }^{95}$ Later, numerous circuit courts wrote opinions that asserted that they in fact did not have the discretion to remand whole cases that included federal questions to state court. Instead, these courts argued that the discretion to remand cases to state court was limited. The reasoning in these cases tends to be thin. For example, in Borough of West Mifflin $v$. Lancaster, ${ }^{96}$ the court first argues that the purpose of changing the language in the remand clause was that Congress was trying to avoid piecemeal litigation. ${ }^{97}$

One could also argue, though, that the congressional intent in changing the language of the remand clause was to accommodate the other changes Congress made in the statute. The other piece of the statute that Congress amended was to restrict the right of removal in $\S$ 1441(c) to claims that fell under $\S 1331$. Previously, $\S 1441(\mathrm{c})$ allowed removal in any instance that the federal court had original jurisdiction. ${ }^{98}$ After Congress decided to restrict the claims that could be removed, the original language, "in its discretion, remand all matters not otherwise within its original jurisdiction," 99 was no longer appropriate. It was no longer appropriate because the federal court was no longer allowed to permit removal of all claims that fell within its original jurisdiction.

The Lancaster court then argues that the "separate and independent" claim requirement of $\S 1441$ (c) restricts the discretionary power of the federal district court. ${ }^{100}$ The court asserts that $\S$ 1441(c) allows for removal or remand only when the federal question claims are separate and independent from state law claims. ${ }^{101}$ The Lancaster court relies on the following authority: "Even if it is assumed that $\S 1441(\mathrm{c})$ would

\footnotetext{
94. Hartnett, supra note 1, at 1159.

95. Id.

96. 45 F.3d 780 (3d Cir. 1995).

97. Id. at 785 .

98. 28 U.S.C. $\S 1441(\mathrm{c})(1990)$.

99. Id.

100. Lancaster, $45 \mathrm{~F} .3 \mathrm{~d}$ at 787.

101. Id. at 786 .
} 
authorize the remand of an entire case, including federal claims, plaintiff must establish that remand of this case would be appropriate under [§] 1441(c)." "102 The court then argues that because only state law claims that are separate and independent may be remanded, there will be no circumstances in which it is allowable to remand a claim in which state law predominates because these claims are not separate and independent. ${ }^{103}$

\section{Critique of and Response to the Majority View}

The plain language of the statute does not posit the same view as the Lancaster court. Instead, the statute requires for removal a separate and independent claim that has federal question jurisdiction joined to the cause of action. On a plain language reading of the statute, the court's discretion to remand is not contingent on the separate and independent requirement. Contrary to the Lancaster court's view, the discretion to remand is contingent on the predominant matter of the claim. If it is predominately state law, then it is permissible to remand the claim to state court.

Congress distinguished the separate and independent requirement clause from the remand clause. If it intended for the separate and independent requirement to apply to the federal district court's discretionary ability to remand, then it would have said "the federal court, in its discretion, may remand all state claims which are separate and independent from the federal claims."

Essentially, the Lancaster court and other circuit courts that have found remand of the entire case to be impermissible are interested in the preservation of removal jurisdiction as it historically has been applied and also are determined to preserve the federal court's subject matter jurisdiction. The court in Hickerson v. City of New York ${ }^{104}$ argued that Congress was not attempting to revolutionize removal jurisdiction with the 1990 amendment to the statute: "Congress was aware, however, of the federal courts' strong view of their obligations to exercise jurisdiction over federal claims properly before them, and it is extremely unlikely that Congress would have used such ambiguous language to accomplish so significant a change in federal jurisdiction." 105 The court also held

102. Id. (quoting Kabealo v. Davis, 829 F. Supp. 923, 926 (S.D. Ohio 1993)).

103. Id.

104. 932 F. Supp. 550 (S.D.N.Y. 1996).

105. Id. at 558 . 
that the "sparse legislative history" "106 that accompanied the 1990 amendments indicated that Congress was not trying to make a dramatic jurisdictional change.

This view probably has merit. If Congress was attempting to make a large change (not even necessarily a revolutionary one), one would expect the modifications and changes in the language of the statute to be accompanied by explanatory legislative history. No extensive legislative history accompanies the 1990 congressional amendments to the statute. ${ }^{107}$ Because Congress did not explain why it intended to allow federal question claims to be remanded, and because the language is ambiguous (as the Hickerson court pointed out), the language should be changed in an amended version of the statute.

Policy considerations weigh in favor of changing the language as well. If a federal question claim is present and removal was appropriate, the defendant deserves to have that claim heard in federal court, where the court is more qualified to apply federal law. It is inane that a defendant could file a motion to remove to federal court, the court would grant the motion - "yes, you are allowed to try this claim in federal court" - and then remand the entire case back to the state court- "but sorry, the whole case is going to be heard in state court." Besides being costly to the defendant, this result is also extremely inefficient. In many cases, the right of removal for the defendant would be illusory, in fact, not a right at all.

\section{The ALI's Proposed Solution}

The ALI suggests the following changes to correct the problem of the potential remand of federal question claims: "Upon such removal [of a federal question claim] the district court shall sever from the action all claims that are not part of the same case or controversy as the claim that is removable under section 1331, and shall remand the severed claims to the State court from which the action was removed."108 The ALI is suggesting several changes. The first change is that the federal district court would no longer have the discretionary power to remand claims back to the state court, instead it would have an obligation to do so.

Second, the ALI is adopting the position that the Lancaster court argues the current statute maintains. To remand claims they must not be

106. Id.

107. 28 U.S.C. $\S 1441$ (c) (2003).

108. AM. LAW INST., supra note 11, at 334; see also 1441(c). 
part of the same case or controversy. ${ }^{109}$ The ALI's suggested amendments make explicit the Lancaster view: ${ }^{110}$ a claim may be removed if within the case there exists a federal question claim that is attached to a nonremovable claim (a state jurisdiction claim) that is not part of the same case or controversy. The same test applies to remand: a claim must ${ }^{111}$ be remanded that is not part of the same case or controversy as the removable claim. ${ }^{112}$

The federal district court may not remand claims where there are both federal law and state law matters. Rather, these claims must stay in federal court. The ALI is preserving the subject matter jurisdiction of the federal court with this amendment to the statute. As it currently stands, the subject matter jurisdiction could at least potentially be compromised in instances where the federal question was predominated by state law.

Moreover, in every case there will be claims that are remanded. Because the federal claim must not be a part of the same case or controversy and because the federal district court is required to "sever from the action all claims that are not part of the same case or controversy" 113 as the removable claim, in every case where removal is allowed some of the claims will return to the state court. Specifically, those unrelated claims to which the removable claim was joined will be remanded.

For example, on the ALI's view, if a plaintiff was suing a defendant for negligence and attached to this claim an unrelated trademark infringement claim, the defendant could file a motion for removal, and the court upon granting removal for the trademark infringement claim would be compelled to remand the negligence claim back to court. However, if the trademark infringement claim was tied to a related contract claim, as a part of the same case or controversy, that state claim would have to stay in federal court. Only the claims that are not part of the same case or controversy as the federal question claim are to be remanded.

The ALI's amended statute seems much better than the current version of $\S 1441(\mathrm{c})$. Its suggestions correct the problem with federal subject matter jurisdiction preservation that the courts have attempted to

109. The ALI changes the language of the statute from "separate and independent" to "same case or controversy" for reasons discussed later in this Comment.

110. See infra Part III.B.2 for a general discussion of the Lancaster view.

111. Here, though, the ALI has changed the "may" to a "must." In the statute as it now stands, the court may remand; if the proposed changes were adopted by Congress, the court would be required to remand federal question claims.

112. AM. LAW INST., supra note 11, at 334.

113. Id. 
correct. But unlike the courts, which engage in elaborate, improbable readings of $\S 1441$ (c) to justify preservation of federal subject matter jurisdiction, Congress, if it adopts the ALI's amended version of $\S$ 1441(c), would not have to disguise its true position behind a veil of thin reasoning.

\section{Assessment of the ALI Proposal}

The only problem immediately visible with the proposed changes is that they command piecemeal litigation. If a remand is granted, then the parties will necessarily be arguing their cases in two different courts. Congress seeks to avoid this result. ${ }^{114}$ But, if it is the case that the only way to preserve federal subject matter jurisdiction is by allowing piecemeal litigation in remand cases, then piecemeal litigation must be allowed.

It is far from certain that Congress will feel the same way, however, as it has tried for many years to prevent piecemeal litigation from arising under $\S 1441(\mathrm{c}) .{ }^{115}$ Presumably, the discretionary remand was given to judges in this instance to avoid piecemeal litigation. Defendants might be deterred from removing cases involving a federal question to federal court because of the time and expense associated with fighting suits in two different courts. Also, if defendants are deterred from removing cases involving a federal question to federal court then state courts will be hearing federal issues. This would inadvertently compromise the subject matter jurisdiction of the federal court.

At least the ALI recommendations clearly state what claims are subject to piecemeal litigation. What remains in federal court, and what is remanded to state court, is specified by the statute. With the ALI's suggested changes, there will be no instances where a removal is granted and then the whole case is remanded. Neither will there be instances where a defendant deserves to have a claim decided by the federal court but is unable to do so because that particular jurisdiction's precedent requires that a claim be remanded if state law predominates. Finally, the courts will not be forced to engage in creative interpretation to produce the correct result.

114. See discussion supra Part II.

115. See discussion supra Part II. 


\section{The Change from "Separate and Independent" to "Not Part of the Same Case or Controversy"}

1. The "Separate-and-Independent" Test

The statute now employs a "separate-and-independent" test, which states that for a claim to be removed, the federal claim must be separate and independent from the nonremovable claims to which it is joined. ${ }^{116}$ The test to determine whether a claim is separate and independent comes from American Fire and Casualty Co. v. Finn. ${ }^{117}$ The Supreme Court maintained in Finn that "where there is a single wrong to plaintiff, for which relief is sought, arising from an interlocked series of transactions, there is no separate and independent claim or cause of action under $\S$ 1441(c)." 118 Thus, if a plaintiff suffers a single injury that occurs as a result of events that are somehow connected, then there are no separate and independent claims in the suit and the defendant does not have the power to remove.

The Finn Court argues that Congress, which changed the test from a removable claim being one that is part of a "separable controversy" to one that is separate and independent, was trying to limit the number of cases that could be removed. ${ }^{119}$ The separable controversy test would allow for removal if there were one cause of action ${ }^{120}$ but multiple parties.

For example, assume $A$ and $B$ are in a car wreck. They sue $C$, the driver, and $D$, the manufacturer of $C$ 's car. Their single injury could have been caused by multiple acts of negligence. As the Court noted in United Mine Workers v. Gibbs: "The mere multiplication of grounds of negligence alleged as causing the same injury does not result in multiplying the causes of action." 121 They could be suing $C$ because $C$ failed to use her brakes in a timely fashion, and $D$ because the faulty brake pads contributed to $C$ 's negligence. The claim against $C$ and the claim against $D$, although part of one cause of action, could be separate controversies.

\footnotetext{
116. AM. LAW INST., supra note $11, \S 1441$, at 333-34.

117. 341 U.S. 6 (1951).

118. Id. at 14 .

119. Id. at 9-10.

120. The term "cause of action" has been notoriously difficult to define. The Finn Court relies on the definition provided by the Court in United Mine Workers of America v. Gibbs: "A cause of action does not consist of facts, but of the unlawful violation of a right which the facts show." 383 U.S. 715, 723 (1966) (citing Baltimore S. S. Co. v. Phillips, 274 U.S. 316, 321 (1927)).

121. Id.
} 
To prevent $C$ or $D$ from removing, Congress changed this separable controversy test. Under the new separate-and-independent test created by Congress, the Finn Court argues that neither $C$ nor $D$ would be able to remove their cases to federal court. ${ }^{122}$ And so the new test does not allow for removal where there is one cause of action and multiple parties. Instead, it demands that a removable claim or cause of action be one that is separate and independent-which on the Finn Court's account means that the claim or cause of action must not arise from the same transaction or series of events. $C$ and $D$ would be unable to remove because the injury suffered by $A$ and $B$ was caused by several negligent events and it was the combination of these events that led to $A$ and $B$ 's single injury.

If, on the other hand, $A$ and $B$ were first hit by $C$, then drove off and were later hit by $E$, and suffered injuries that could be directly attributable to the respective wrecks, it would probably be possible for $C$ and $E$ to remove. $A$ and $B$ suffered two harms, and the events were not necessarily related.

\section{The ALI's Recommendation and the Relationship Test}

The ALI feels that the separate-and-independent test is murky and introduces unnecessary ambiguity into the statute. ${ }^{123}$ It finds the separate-and-independent test to be "historically uncertain." 124 The commentary does not indicate why the ALI feels the statute is historically uncertain. Presumably, the uncertainty lies in the application of the test to complicated sets of facts, uncertainty about the definitions of "cause of action" and "claim," and uncertainty about the congressional intent in enacting the separate-and-independent test.

To eliminate the historical uncertainty associated with a removable claim being one that is "separate and independent," the ALI changes the language to the following: if a claim is not removable solely because a nonremovable claim has been joined to it that is "not part of the same case or controversy under Article III of the Constitution," then the action may be removed. ${ }^{125}$ This language mirrors the language in 28 U.S.C. $\S$ 1367(a). ${ }^{126}$ Section 1367(a) asserts that the district courts have

\footnotetext{
122. In this example, there is no federal question, so the federal court would not have jurisdiction, but please ignore this. Instead, focus on the separate-and-independent test, which this example illustrates.

123. AM. LAW INST., supra note 11, at 372.

124. Id. at 372 .

125. Id.

126. 28 U.S.C. $§ 1367$ (a) (2003).
} 
supplemental jurisdiction over "all other claims that are so related to claims in the action within such original jurisdiction that they form part of the same case or controversy under Article III of the United States Constitution."127

This language is referred to as the "relationship test." Congress sought to codify the results from several pendent and ancillary jurisdiction cases, including Gibbs, from which the relationship test comes. ${ }^{129}$ When Congress codified the doctrines in the cases, it gave them the collective name "supplemental jurisdiction." the relationship test as having two parts. ${ }^{131}$ First, supplemental jurisdiction exists when there is a claim "arising under [the] Constitution, the Laws of the United States, and Treaties made, or which shall be made, under their Authority." 132 Second, "the relationship between that claim and the state claim permits the conclusion that the entire action before the court comprises but one constitutional "case.",133 To comprise one case the state and federal claims must derive from "a common nucleus of operative fact." 134

The ALI's proposed $\S 1441$ (c) would use the same test. ${ }^{135}$ For a claim to be removable, it must be joined to a nonremovable claim that is not part of the same case or controversy under Article III of the Constitution. Thus, the nonremovable claim itself must first be one that is not part of the same case or controversy. As directed then by Gibbs, the claim must not derive from a common nucleus of operative fact. ${ }^{136}$ Second, the nonremovable claim must not arise under Article III of the Constitution. Thus, the claim must be a state claim.

\section{Assessment of the ALI's Position}

The suggested language is modestly redundant. Obviously the nonremovable claim must be a state claim, otherwise the whole case could be tried in federal court. If there were not a nonremovable claim

127. Id

128. AM. LAW INST., supra note 11, at 372.

129. John J. Cound, Jack H. Friedenthal, Arthur R. Miller, \& John E. Sexton, Civil PROCEDURE 298 (8th ed. 2004).

130. Id.

131. United Mine Workers v. Gibbs, 383 U.S. 715, 725 (1986).

132. U.S. CONST. art. III, § 2 .

133. Gibbs, 383 U.S. at 725.

134. Id.

135. AM. LAW INST., supra note 11, at 372.

136. Gibbs, 383 U.S. at 725. 
present, then the case would be controlled by $\S 1441(a)$, which allows the removal to federal court those cases that fall entirely under federal jurisdiction. So, the inclusion of the "under Article III of the Constitution" language is probably unnecessary. However, because the ALI wants to indicate that the same test used for supplemental jurisdiction applies to removal jurisdiction in $\S 1441(\mathrm{c})$, perhaps reciting the exact same language is necessary to make this fact clear.

It is better to make the language in $\S 1441$ (c) parallel the language in $\S 1367$, the supplemental jurisdiction statute. With both the separate and independent test and the relationship test, the statutes are indicating that the same result is necessary to either hear the state claim in federal court (for supplemental jurisdiction) or to allow a federal claim to be removed to federal court instead of being heard in state court. In both instances, it is necessary to decide whether (at least) two claims are related in such a way that it would be inconvenient or difficult to separate them.

For example, if two claims share a substantially similar set of facts, it is not possible for them to be tried in two different courts-because the separate courts could decide the facts differently. So, to remove a claim, or to keep a claim for supplemental jurisdiction, the relationship between the claims must be inspected. Thus, there is no reason to provide two different tests by which to judge the relatedness of a state and federal claim. Ockham's razor tells us it is much more sensible to provide one test for both statutes.

Further, the ALI's suggestion to change the separate-andindependent test to the relationship test in the removal statute should appeal to Congress. The suggested change does not allow more cases to be removed to federal court. This is appealing to Congress because it has indicated that it wishes to restrict the power to remove. ${ }^{137}$ Instead, the recommendation of the ALI simply clarifies a statute that was not as clear as it could be. If Congress adopts the ALI's recommendations, courts and attorneys should be pleased as well, because now a single test exists to determine whether multiple claims are so related that they may be heard in the same court.

\section{CONCLUSION}

There is no question that $\S 1441(\mathrm{c})$ is in desperate need of revision. The suggested amendments by the ALI seem to solve most of the problems that arise with the current statute. If its revisions were enacted, 
many of the standing problems with the statute would disappear, and the ambiguity that exists in the statute now would be greatly diminished.

The most problematic suggestion made by the ALI is that the court's discretionary power to remand cases be abolished. It is advocating a revision that does not merely encourage but demands piecemeal litigation. Congress has revised the statute many times both to avoid piecemeal litigation and to let courts and practitioners know that piecemeal litigation is at best a last resort with regard to removal jurisdiction. As it stands now, piecemeal litigation is mostly an unnecessary response to a removal under $\S 1441(c)$. Because the court has the discretion to either keep all claims in the case or to remand some of the claims (currently, as discussed, it even appears that the courts can send federal questions back to the state court), then circumstances demanding piecemeal litigation will rarely arise.

The ALI's proposed changes will require piecemeal litigation because the judge no longer has the discretion to decide whether to keep the case. Instead, she must remand to state court all claims not a part of the same case or controversy as the federal claim. Because the ALI's suggested revision of $\S 1441$ (c) requires that in order to remove, it is necessary for a state claim to not be a part of the same case or controversy, then the court in every case will have to remand that state claim back to the state court. Thus, piecemeal litigation will occur every time removal is granted. Surely Congress will be disinclined to find this suggested change acceptable.

Perhaps the ALI could have suggested a more conservative change that corrected the "in which State law is predominate" problem. Surely the ALI could preserve the right of federal courts to hear cases where they have subject matter jurisdiction without disallowing judges the discretionary power to keep or remand state claims.

Further, the ALI's disregard for the controversy surrounding the ability of third-party, cross-claim, and counterclaim defendants to remove also seems unhelpful. Although it adopts the position that many courts have adopted, it ignores the fact that many other courts have decided these cases differently. Among federal district courts, there is no uniform application of the law to this special class of defendants. Perhaps the ALI should have addressed this or tried to come to a better compromise position. It is unclear what right of removal Congress thinks third-party, cross-claim, and counterclaim defendants have or ought to have. In the proceeds from the Federal Judicial Code Revision Project, it should at least be noted that the courts are split as to whether these defendants have the right to remove. 
The proposal for changing the separate-and-independent test to the relationship test used in the supplemental jurisdiction statute is good. Although the separate-and-independent test presents no insurmountable problems, the suggestion is good because it reduces the number of tests that the court is compelled to apply to reach the same result. This change can only result in consistency among decisions in similar but different areas of the law.

Congress would be wise to adopt most of the ALI's suggestions regarding $\S 1441(\mathrm{c})$. However, it is unlikely that Congress will adopt the suggestion that destroys the court's discretionary power to remand, and it is not clear that it should. Although the changes suggested by the ALI do not make the statute perfect, they certainly clear up many of the problems that have arisen as a result of the current statutory language. 